\title{
Glucagon Cell Hyperplasia and Neoplasia
}

National Cancer Institute

\section{Source}

National Cancer Institute. Glucagon Cell Hyperplasia and Neoplasia. NCI Thesaurus. Code C157461.

An extremely rare autosomal recessive inherited disorder caused by mutations in the GCGR gene. It is characterized by the presence of islet glucagon cell hyperplasia and glucagon cell tumors. 